\title{
Correlation between gastric carcinoma and ZAC gene-associated microsatellite instability and loss of heterozygosity
}

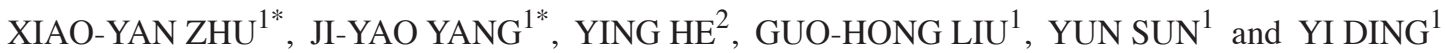 \\ Departments of ${ }^{1}$ Histology and Embryology, and ${ }^{2}$ Cell Biology and Genetics, \\ Basic Medical College, Zhengzhou University, Zhengzhou, Henan 450001, P.R. China
}

Received February 1, 2016; Accepted March 17, 2017

DOI: $10.3892 / \mathrm{ol} .2017 .6384$

\begin{abstract}
The present study explored the association between loss of heterozygosity $(\mathrm{LOH})$ or microsatellite instability (MSI) of the zinc finger regulator of apoptosis and cell-cycle arrest (ZAC) gene and the clinicopathological factors of gastric cancer. Samples of cancer and cancer-adjacent normal tissue from 30 patients with gastric cancer were collected. The genomic DNA was extracted from each and amplified with primers specific to ZAC microsatellite mutations, then run on a polyacrylamide gel for analysis. The CA197 microsatellite locus exhibited $\mathrm{LOH}$ in cancer sample 4 . There was $\mathrm{LOH}$ in the 15AAAG locus in cancer sample 27 and cancer-adjacent tissue 23, and MSI at 15AAAG in cancer-adjacent tissue 27. There was MSI at the D6S1703 microsatellite locus in cancer-adjacent tissue 28. There was no LOH or MSI in the CA340 microsatellite locus in the gastric cancer or adjacent tissues analyzed. Thus, the frequency of LOH or MSI at ZAC gene-associated microsatellite loci for all patients was $13.3 \%$ (4/30). The present study has demonstrated that LOH and MSI events may contribute to the downregulation of ZAC; however, it is unlikely to be the primary cause, as it was only identified in $13.3 \%$ of cases.
\end{abstract}

\section{Introduction}

Zinc finger regulator of apoptosis and cell cycle arrest (ZAC) occurs within the chromosomal region 6q24. The zinc finger protein encoded by ZAC acts as a transcription factor, and there is substantial evidence for its role as a tumor suppressor (1). ZAC inhibits tumor cell proliferation through the induction of apoptosis and cell cycle arrest. ZAC has been implicated

Correspondence to: $\mathrm{Dr} \mathrm{Yi}$ Ding, Department of Histology and Embryology, Basic Medical College, Zhengzhou University, 100 Science Avenue, Zhengzhou, Henan 450001, P.R. China

E-mail:dingyi@zzu.edu.cn

*Contributed equally

Key words: ZAC gene, microsatellite instability, loss of heterozygosity in tumorigenesis in a number of types of cancer; loss or downregulation of expression has thus far been identified in ovarian cancer (2), breast cancer (3), head and neck squamous cell carcinoma (4), nonfunctioning pituitary adenomas (5) and extra-skeletal myxoid chondrosarcoma (6). The molecular mechanism for the alteration in ZAC gene expression in gastric cancer tissues is unclear. Downregulation of tumor suppressor genes in cancer tissue may occur as the consequence of one or more genetic or epigenetic events. Genetic alterations include the mutation of the protein-coding region or loss of heterozygosity ( $\mathrm{LOH})$ and microsatellite instability (MSI) in the coding or non-coding regions. Epigenetic changes typically involve the methylation of promoter DNA or histone acetylation (7).

Microsatellite sequences are highly polymorphic, short tandem repeat sequences that occur in the human genome. They may be situated in the exon, intron or promoter regions. MSI is the polymorphism in the length of these microsatellite sequences; they may affect amino acid codons or the regulation of transcription (8). At present, various MSI phenotypes have been identified in a number of tumor types $(7,8)$. The mechanism of inactivating mutations and deletions of both alleles of a tumor suppressor gene was involved in the process of carcinogenesis. Loss of heterozygosity $(\mathrm{LOH})$ may increase cancer susceptibility, particularly following exposure to environmental carcinogens (9).

LOH or MSI can cause functional abnormality of the associated gene when they occur in protein coding regions, or lead to gene expression abnormalities in non-coding regions. In this study, four ZAC-associated microsatellite loci were selected for examination in gastric cancer tissues using a polymerase chain reaction (PCR)-PAGE-silver staining technique in order to explore LOH/MSI-associated mechanisms for the downregulation of ZAC expression in cancer. The association between $\mathrm{LOH} / \mathrm{MSI}$ of the ZAC gene and clinicopathological factors in gastric cancer was also analyzed.

\section{Patients and methods}

Sample collection. Samples including cancer tissue, the tissue adjacent to cancer and normal gastric mucosal tissues, were collected from 30 patients with gastric cancer and preserved in liquid nitrogen. The gastric cancer samples were obtained from surgical patients of the Department of Gastroenterology, Cancer 
Hospital of Henan (Zhengzhou, China). The gastric cancer tissues were collected from patients undergoing gastrectomy from March 2014 to December 2014. All patients were informed of the aims of specimen collection and provided written consent in accordance with the ethical guidelines of Cancer Hospital of Henan. The investigations were conducted according to the principles of the Declaration of Helsinki, and the Ethical Committee of Zhengzhou University approved the study.

Extraction of genomic DNA. Tissue from each sample $(0.5 \mathrm{~g})$ was ground and mixed with an equal amount of $2 \mathrm{X}$ Triton lysate mix. Following centrifugation $\left(12,000 \mathrm{rpm}, 5 \mathrm{~min}, 4^{\circ} \mathrm{C}\right)$, the sediment was incubated with EDTA- $\mathrm{Na}_{2}$ proteinase K-SDS mixture. It was treated three times with phenol, phenol-chloroform-isoamyl alcohol mixture and chloroform-isoamyl alcohol mixture in sequence, respectively. The DNA product was precipitated with anhydrous isopropanol and dissolved in Tris-EDTA buffer. It was then stored at $-20^{\circ} \mathrm{C}$. The integrity of genomic DNA was evaluated by $1 \%$ agarose gel electrophoresis, and the purity was determined using the $\mathrm{A}_{260} / \mathrm{A}_{280}$ absorbance value measured with a spectrophotometer.

$P C R$ reaction. Based on the sequences of the $\mathrm{ZAC}$-associated microsatellite loci CA197, 15AAAG, CA340 and D6S1703 as reported in GenBank (Gene ID: 5325; PMID:11313869; DOI: 10.1038/sj.onc.1204237), four pairs of PCR primers were designed using Primer3 online primer design software (Primer 3 Input 0.4.0; http://frodo.wi.mit.edu/). The PCRs were performed in the corresponding reaction systems, consisting of $10 \mu 12 X$ Taq PCR Mastermix (Shanghai Sangon Biological Engineering Technology \& Services Co., Ltd., Shanghai, China), $0.9 \mu \mathrm{l}$ forward primer, $0.9 \mu \mathrm{l}$ reverse primer, $1 \mu \mathrm{l}$ template DNA (50 ng/ $\mu \mathrm{g}$ ) and $7.2 \mu \mathrm{l}$ water. The PCR products were run on $2 \%$ agarose gel to examine amplified results.

CA197. For the detection of CA197 (CA) fragments, the following primers were used: Forward, TTTATATGTTGC ATTTCCTTT; reverse, CAAACCATGGCACACATATACC. PCR conditions were as follows: $95^{\circ} \mathrm{C}$ for $5 \mathrm{~min}$ followed by 38 cycles of $95^{\circ} \mathrm{C}$ for $30 \mathrm{sec}$, annealing at $52^{\circ} \mathrm{C}$ for $30 \mathrm{sec}$ and extension at $72^{\circ} \mathrm{C}$ for $45 \mathrm{sec}$, followed by a final extension step of $72^{\circ} \mathrm{C}$ for $7 \mathrm{~min}$.

$15 A A A G$. For the detection of 15AAAG (CTTT) fragments, the following primers were used: Forward, CCTCACCTGCAG TTTTGCT; reverse, GTGACAGAGAAAGACCCCAACT. PCR conditions: $95^{\circ} \mathrm{C}$ for $5 \mathrm{~min}$ followed by 35 cycles of $95^{\circ} \mathrm{C}$ for $30 \mathrm{sec}$, annealing at $58^{\circ} \mathrm{C}$ for $30 \mathrm{sec}$ and extension at $72^{\circ} \mathrm{C}$ for $45 \mathrm{sec}$, followed by a final extension step of $72^{\circ} \mathrm{C}$ for $7 \mathrm{~min}$.

CA340. For the detection of CA340 (AT) fragments, the following primers were used: Forward, AGAGTTTGCAGT GAGCCAAGAT; reverse, TCTCCTCACTCCCTTTCACTT C. PCR conditions: $95^{\circ} \mathrm{C}$ for 5 min followed by 42 cycles of $95^{\circ} \mathrm{C}$ for $30 \mathrm{sec}$, annealing at $54^{\circ} \mathrm{C}$ for $30 \mathrm{sec}$ and extension at $72^{\circ} \mathrm{C}$ for $45 \mathrm{sec}$, followed by a final extension step of $72^{\circ} \mathrm{C}$ for $7 \mathrm{~min}$.

D6S1703. For the detection of $(\mathrm{CA})_{\mathrm{n}}$ fragments, the following primers were used: Forward, CTGGTGCTGATGTATCCA
AAAT; reverse, TTTGGAGGATCAGGAAAGAAAA. PCR conditions: $95^{\circ} \mathrm{C}$ for 5 min followed by 35 cycles of $95^{\circ} \mathrm{C}$ for $30 \mathrm{sec}$, annealing at $55^{\circ} \mathrm{C}$ for $30 \mathrm{sec}$ and extension at $72^{\circ} \mathrm{C}$ for $45 \mathrm{sec}$, followed by a final extension step of $72^{\circ} \mathrm{C}$ for $7 \mathrm{~min}$.

Determination of MSI and $\mathrm{LOH}$. The PCR products were run on a $6 \%$ polyacrylamide gel at $550 \mathrm{~V}$ for $2.5 \mathrm{~h}$. Following electrophoresis, the gel was fixed with $10 \%$ ethyl alcohol for $10 \mathrm{~min}$ at room temperature. The gel was oxidized with nitric acid for $2 \mathrm{~min}$ and stained with silver nitrate solution $15 \mathrm{~min}$ at room temperature. Sodium carbonate-formaldehyde solution was added to color the gel 3 times, then the staining reaction was terminated through the addition of acetic acid (10\%) at room temperature. If the density of a band was not present or lowered to that that of $50 \%$ of normal tissue, it was defined as $\mathrm{LOH}$. If the density of the band was more than that of normal tissue, it was defined as MSI.

\section{Results}

CA197. The amplified $(\mathrm{CA})_{\mathrm{n}}$ fragment size was $240 \mathrm{bp}$ (Fig. 1A). A single LOH event was observed at this locus in the tumor tissue from case 4 , equating to an incidence of $3.3 \%$ (1/30; Fig. 1B). There were no incidences of MSI at this locus in the cancer tissue samples, or incidences of LOH or MSI in the cancer-adjacent tissue.

15AAAG. The amplified (CTTT) $)_{\mathrm{n}}$ fragment size was $173 \mathrm{bp}$ (Fig. 2A). There was a single $\mathrm{LOH}$ event at this locus in sample 27, an incidence of $3.3 \%$ (1/30; Fig. 2B). No incidences of MSI were detected at this locus in the cancer tissue; however, cancer-adjacent tissue from sample 27 exhibited MSI at this locus (incidence, $3.3 \%$; Fig. 2B). In the cancer-adjacent tissue of case 23 there was one $\mathrm{LOH}$ event at this locus (incidence, 3.3\%; Fig. 2C).

D6S1703. The amplified (CA) fragment length was 223 bp (Fig. 3A). In the cancer-adjacent tissue of one case (case 28) an MSI event was detected (incidence, 3.3\%; Fig. 3B). No other MSI or microsatellite LOH events were detected at this locus in any tissue.

CA340. The amplified (AT) fragment length was $247 \mathrm{bp}$ (Fig. 4). No cancer or cancer-adjacent tissue samples exhibited MSI or LOH at this locus.

Association between MSI/LOH and clinicopathological variables. As presented in Table II, all four cases of moderately-differentiated gastric cancer were negative for MSI/LOH. In the 26 cases of poorly-differentiated gastric cancer, 4 cases were MSI/LOH positive (Table I), including 1 case at clinical stage I/II and 3 cases at stage III/IV. These were staged according to the tumor-node-metastasis classification system and graded into five groups [the TNM classification UICC 2009, 7th edition (10)]: Stage 0 (TisN0M0, n=0), Stage I (T1N0-1M0, T2N0M0, n=8), Stage II (T1N2-3M0, T2N1-2M0, T3N0M0, T4aN0M0, n=64), Stage III (T2N3M0, T3N2-3M0, T4aN1-3M0, T4bN0-3M0, $\mathrm{n}=73$ ), Stage IV (TanyNanyM1, $\mathrm{n}=8)$. 
Table I. ZAC-associated MSI and LOH events detected in 30 paired cancer and cancer-adjacent tissue samples from patients with gastric cancer.

\begin{tabular}{|c|c|c|c|c|c|c|c|c|}
\hline \multirow[b]{2}{*}{ Tissue } & \multicolumn{2}{|c|}{ CA197 } & \multicolumn{2}{|c|}{ 15AAAG } & \multicolumn{2}{|c|}{ D6S1703 } & \multicolumn{2}{|c|}{ CA340 } \\
\hline & LOH & MSI & $\mathrm{LOH}$ & MSI & $\mathrm{LOH}$ & MSI & $\mathrm{LOH}$ & MSI \\
\hline Cancer tissue, $\mathrm{n}$ & 1 & 0 & 1 & 0 & 0 & 0 & 0 & 0 \\
\hline Adjacent tissue, $\mathrm{n}$ & 0 & 0 & 1 & 1 & 0 & 1 & 0 & 0 \\
\hline
\end{tabular}

ZAC, zinc finger regulator of apoptosis and cell-cycle arrest; MSI, microsatellite instability; LOH, loss of heterozygosity.

Table II. ZAC gene microsatellite locus event association with clinicopathological indicators in gastric cancer.

\begin{tabular}{|c|c|c|}
\hline Characteristic & Patients, $\mathrm{n}$ & $\begin{array}{c}\mathrm{ZAC} \mathrm{MSI/LOH} \\
\text { cases, } \mathrm{n}\end{array}$ \\
\hline \multicolumn{3}{|l|}{ Sex } \\
\hline Male & 24 & 4 \\
\hline Female & 6 & 0 \\
\hline \multicolumn{3}{|l|}{ Age } \\
\hline$<60$ & 18 & 2 \\
\hline$\geq 60$ & 12 & 2 \\
\hline \multicolumn{3}{|l|}{ Tumor diameter } \\
\hline$<5 \mathrm{~cm}$ & 16 & 2 \\
\hline$\geq 5 \mathrm{~cm}$ & 14 & 2 \\
\hline \multicolumn{3}{|c|}{ Histopathological classification } \\
\hline Moderately differentiated & 4 & 0 \\
\hline Poorly differentiated & 26 & 4 \\
\hline \multicolumn{3}{|l|}{ Clinical stage } \\
\hline I or II & 14 & 1 \\
\hline III or IV & 16 & 3 \\
\hline
\end{tabular}

ZAC, zinc finger regulator of apoptosis and cell-cycle arrest.

\section{Discussion}

ZAC expression has previously been identified to be downregulated or eliminated in a variety of solid cancer types, including breast (3), ovarian $(2,11,4)$, head and neck squamous cell carcinoma (4), pheochromocytoma (12) and pituitary adenoma (5). Differences in the frequency of ZAC gene $\mathrm{LOH}$ in the tumor lead to the downregulation of ZAC (13). In previous reports, the frequency of ZAC gene LOH in ovarian (11), breast (3) and squamous cell carcinoma (4) tumors was $36.4,40$ and $31.4 \%$, respectively; in B-cell lymphoma, $\mathrm{LOH}$ was identified in $23 \%$ (3/11) of cases (8). Screening in colorectal cancer revealed an LOH for at least one marker in half of the cases, but no mutations in the ZAC coding region (14). Including all 6q23-25 ZAC-specific microsatellite markers, which differ to those used in the present study. $\mathrm{LOH}$ or allele imbalance was detected in 50\% (9/18) of pheochromocytomas (5). In the present study, microsatellite LOH or MSI occurred in $13.3 \%$ (4/30) of gastric cancer cases, demonstrating that ZAC gene

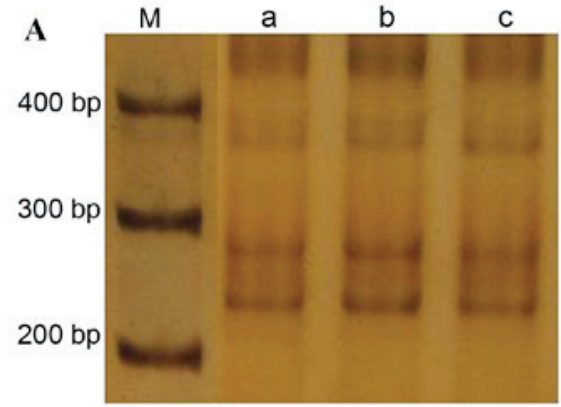

B

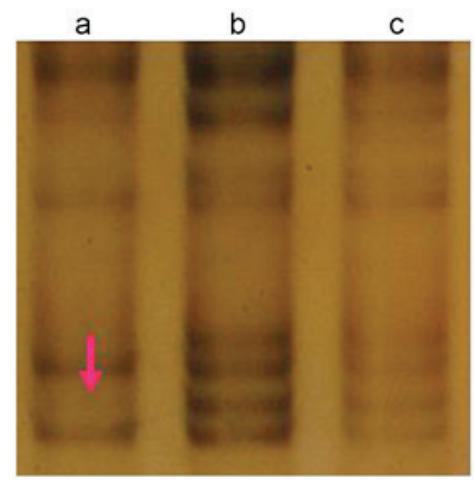

Figure 1. PAGE following amplification at the CA197 ZAC-associated microsatellite locus. (A) An example with no abnormal cases. (B) Case number 4, in which there was a loss of heterozygosity at this locus in the gastric cancer tissue (pink arrow). ZAC, zinc finger regulator of apoptosis and cell-cycle arrest; M, marker; a, gastric cancer tissues; b, tissue adjacent to a; c, normal gastric mucosa tissues.

microsatellite LOH/MSI may be one of the molecular mechanisms underlying ZAC gene downregulation in gastric cancer tissue.

$\mathrm{ZAC}$ is a maternally imprinted gene (12). If the paternal allele were lost, ZAC gene expression would not be influenced; if the maternal allele were lost, ZAC gene expression would be silenced, causing ZAC downregulation $(12,13)$. However, it was not possible to check which allele was lost in the present study.

A study by Jarmalaite et al (12) demonstrated that the rate of ZAC gene expression in gastric cancer was $33.3 \%$, markedly below the $66.6 \%$ of normal gastric mucosa tissues. A LOH/MSI frequency of $13.3 \%$, as identified in the present study, would be insufficient to explain the low levels of ZAC gene expression in gastric cancer, as observed in the study by Jarmalaite et al (12). The study further determined that that $29.5 \%$ of gastric cancer samples exhibited ZAC promoter 

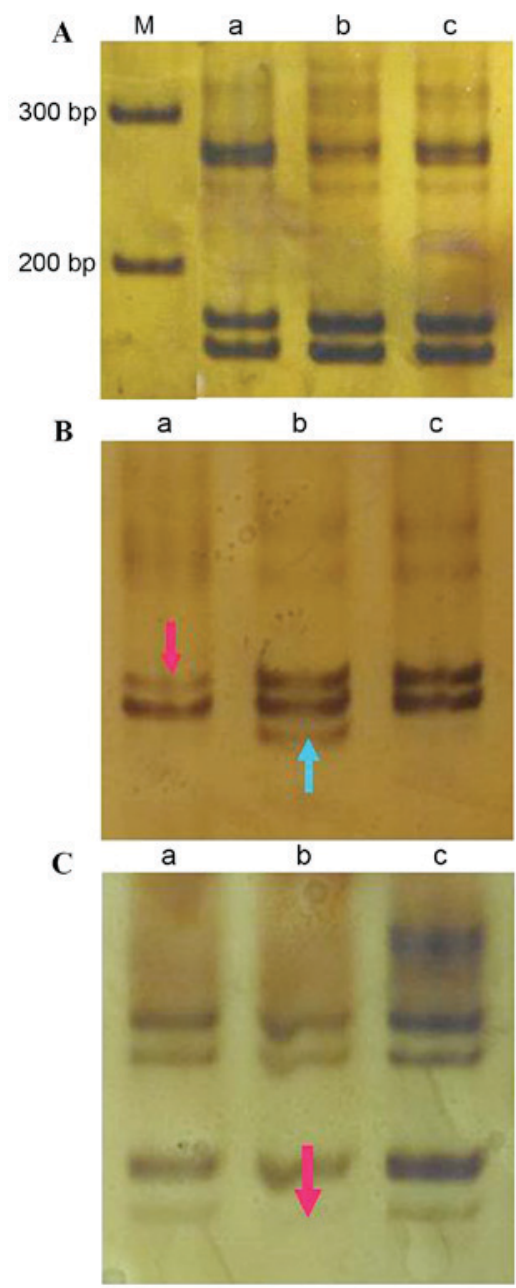

Figure 2. PAGE following amplification at the 15 AAAG ZAC-associated microsatellite locus. (A) An example with no abnormal events. (B) Case number 27, in which there was loss of heterozygosity in adjacent tissue (pink arrow), and microsatellite instability in cancer tissue (blue arrow), at this locus. (C) Case number 23, in which there was a loss of heterozygosity at this locus in the tissue adjacent to carcinoma (pink arrow). ZAC, zinc finger regulator of apoptosis and cell-cycle arrest; M, marker; a, gastric cancer tissues; $\mathrm{b}$, tissue adjacent to a; c, normal gastric mucosa tissues.

methylation and that a high rate ZAC promoter methylation is associated with the loss of ZAC expression in gastric cancer tissue (12). Therefore, in gastric cancer tissue, alterations to ZAC function may be a result of genetic and epigenetic modifications.

A high rate of MSI has been associated with the development of multiple primary colorectal carcinomas (14). The rate of MSI has also been demonstrated to be associated with gastric cancer clinical pathology (15). A previous study revealed that MSI events in gastric cancer were more likely in women and with increasing age, and that they were associated with poor tumor differentiation (16). Another study reported that MSI was not associated with any index of clinical pathology in familial gastric cancer, whereas MSI was more likely in women and with increasing age, and was associated with the intestinal subtype in sporadic gastric cancer (17). A further study of gastric cancer by Seo et al (18) identified associations between a high MSI frequency and increasing age, tumor size and intestinal subtype. Another previous study demonstrated

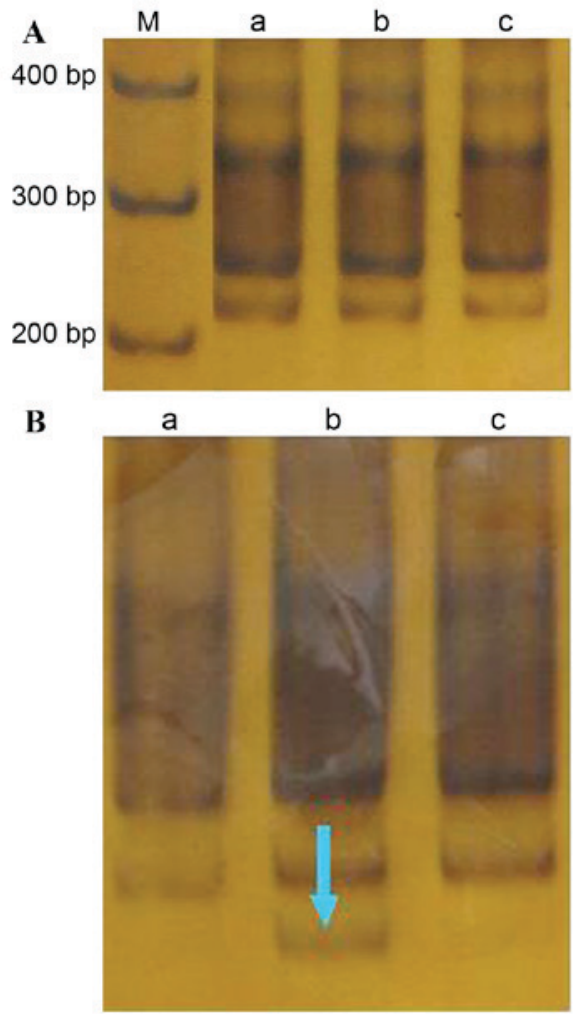

Figure 3. PAGE following amplification at the D6S1703 ZAC-associated microsatellite locus. (A) An example with no abnormal cases. (B) A case where there was microsatellite instability at this locus in the cancer-adjacent tissue (blue arrow). ZAC, zinc finger regulator of apoptosis and cell-cycle arrest; M, marker; a, gastric cancer tissues; b, tissue adjacent to a; c, normal gastric mucosa tissues.

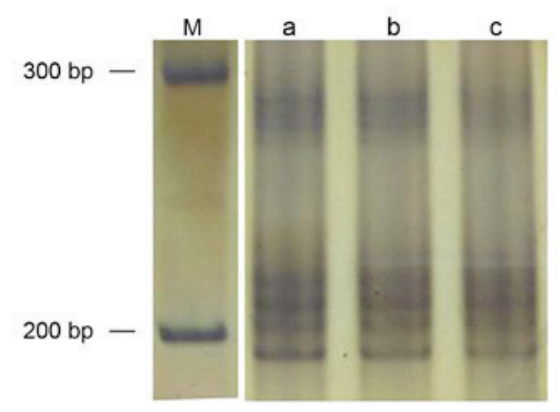

Figure 4. PAGE following amplification at the CA340 ZAC-associated microsatellite locus. No abnormal cases were detected in PAGE. ZAC, zinc finger regulator of apoptosis and cell-cycle arrest; M, marker; a, gastric cancer tissues; b, tissue adjacent to a; c, normal gastric mucosa tissues.

that the rate of $\mathrm{LOH}$ in p16 microsatellite loci did not significantly differ between gastric cancer tumors with moderate and poor levels of differentiation (19).

The present study has demonstrated that LOH and MSI events may contribute to the downregulation of ZAC; however, it is unlikely to be the primary cause, as it was only identified in $13.3 \%$ of cases. In the present study, all four patients exhibiting MSI/LOH were male with a poorly-differentiated adenocarcinoma, including three cases of stage III-IV and one case of stage I-II, suggesting a trend between MSI/LOH occurrence and poorly-differentiated, advanced-stage tumors. However, the low number of participants, including just four 
female patients and four moderately-differentiated tissue specimens, limits the present study. In order to determine whether ZAC gene-associated LOH/MSI is associated with sex, tumor differentiation and clinical stage in gastric cancer, further studies with a larger sample size are required. In order to explore the underlying mechanism of ZAC gene downregulation in gastric cancer, our future study will aim to detect the methylation of the ZAC gene promoter, and the levels of ZAC mRNA and protein expression, and to analyze the relationship between methylation, MSI/LOH and ZAC gene expression.

\section{References}

1. Spengler D, Villalba M, Hoffmann A, Pantaloni C, Houssami S, Bockaert $\mathrm{J}$ and Journot L: Regulation of apoptosis and cell cycle arrest by Zac1, a novel zinc finger protein expressed in the pituitary gland and the brain. EMBO J 16: 2814-2825, 1997.

2. Cvetkovic D, Pisarcik D, Lee C, Hamilton TC and Abdollahi A: Altered expression and loss of heterozygosity of the LOT1 gene in ovarian cancer. Gynecol Oncol 95: 449-455, 2004.

3. Bilanges B, Varrault A, Basyuk E, Rodriguez C, Mazumdar A, Pantaloni C, Bockaert J, Theillet C, Spengler D and Journot L: Loss of expression of the candidate tumor suppressor gene ZAC in breast cancer cell lines and primary tumors. Oncogene 18 : 3979-3988, 1999.

4. Koy S, Hauses M, Appelt H, Friedrich K, Schackert HK and Eckelt U: Loss of expression of ZAC/LOT1 in squamous cell carcinomas of head and neck. Head Neck 26: 338-344, 2004.

5. Pagotto U, Arzberger T, Theodoropoulou M, Grübler Y,Pantaloni C, Saeger W, Losa M, Journot L, Stalla GK and Spengler D: The expression of the antiproliferative gene ZAC is lost or highly reduced in nonfunctioning pituitary adenomas. Cancer Res 60: 6794-6799, 2000

6. Poulin H and Labelle Y: The PLAGL1 gene is down-regulated in human extraskeletal myxoid chondrosarcoma tumors. Cancer Lett 227: 185-191, 2005 .

7. Chatterton Z, Burke D, Emslie KR, Craig JM, Ng J, Ashley DM, Mechinaud F, Saffery R and Wong NC: Validation of DNA methylation biomarkers for diagnosis of acute lymphoblastic leukemia. Clin Chem 60: 995-1003, 2014.

8. Valleley EM, Cordery SF, Carr IM, MacLennan KA and Bonthron DT: Loss of expression of ZAC/PLAGL1 in diffuse large B-cell lymphoma is independent of promoter hypermethylation. Genes Chromosomes Cancer 49: 480-486, 2010.
9. Jahng J, Youn YH, Kim KH, Yu J, Lee YC, Hyung WJ, Noh SH, Kim H, Kim H, Park H and Lee SI: Endoscopic and clinicopathologic characteristics of early gastric cancer with high microsatellite instability. World J Gastroenterol 18: 3571-3577, 2012.

10. Kikuchi S, Futawatari N, Sakuramoto S, Katada N, Yamashita K, Shibata T, Nemoto $M$ and Watanabe M: Comparison of staging system between the old (6th edition) and new (7th edition) TNM classifications in advanced gastric cancer. Anticancer Res 31: 2361-2365, 2011.

11. Kamikihara T, Arima T, Kato K, Matsuda T, Kato H, Douchi T, Nagata Y, Nakao M and Wake N: Epigenetic silencing of the imprinted gene ZAC by DNA methylation is an early event in the progression of human ovarian cancer. Int J Cancer 115: 690-700, 2005.

12. Jarmalaite S, Laurinaviciene A, Tverkuviene J, Kalinauskaite N, Petroska D, Böhling T and Husgafvel-Pursiainen K: Tumor suppressor gene ZAC/PLAGL1: Altered expression and loss of the nonimprinted allele in pheochromocytomas. Cancer Genet 204: 398-404, 2011.

13. Ankolkar M, Salvi V, Warke H, Vundinti BR and Balasinor NH: Methylation status of imprinted genes DLK1-GTL2, MEST (PEG1), ZAC (PLAGL1), and LINE-1 elements in spermatozoa of normozoospermic men, unlike H19 imprinting control regions, is not associated with idiopathic recurrent spontaneous miscarriages. Fertil Steril 99: 1668-1673, 2013.

14. Kawakami H, Zaanan A and Sinicrope FA: Microsatellite instability testing and its role in the management of colorectal cancer. Curr Treat Options Oncol 16: 30, 2015.

15. Yamashita K, Arimura Y, Kurokawa S, Itoh F, Endo T, Hirata K, Imamura A, Kondo M, Sato T and Imai K: Microsatellite instability in patients with multiple primary cancers of the gastrointestinal tract. Gut 46: 790-794, 2000.

16. Polom K, Marrelli D, Roviello G, Pascale V, Voglino C, Rho H, Marini M, Macchiarelli R and Roviello F: Molecular key to understand the gastric cancer biology in elderly patients-The role of microsatellite instability. J Surg Oncol 115: 344-350, 2017.

17. Pedrazzani C, Corso G, Velho S, Leite M, Pascale V, Bettarini F, Marrelli D, Seruca R and Roviello F: Evidence of tumor microsatellite instability in gastric cancer with familial aggregation. Fam Cancer 8: 215-220, 2009.

18. Seo HM, Chang YS, Joo SH, Kim YW, Park YK, Hong SW and Lee SH: Clinicopathologic characteristics and outcomes of gastric cancers with the MSI-H phenotype. J Surg Oncol 99: $143-147,2009$.

19. Zhang QX, Ding Y, Le XP and Du P: Studies on microsatellite instability in p16 gene and expression of hMSH2 mRNA in human gastric cancer tissues. World J Gastroenterol 9: 437-441, 2003. 